v. $10, n .4$

Vitória-ES, Out.-Dez. 2013

p. 91 - 109 ISSN 1808-2386 DOI: http://dx.doi.org/10.15728/bbr.2013.10.4.4

\title{
Earnings management in Brazilian credit unions*
}

\author{
Saulo Cardoso Maia ${ }^{\dagger}$ \\ Centre for Higher Education Lafaiete
}

Valéria Gama Fully Bressan $^{\Omega}$

Federal University of Minas Gerais

Wagner Moura Lamounier ${ }^{*}$

Federal University of Minas Gerais

\author{
Marcelo José Braga ${ }^{t}$ \\ Federal University of Viçosa
}

\begin{abstract}
This article investigates the practice of earnings management by Brazilian credit unions. The main focus is to check for the existence of earnings management to meet the capital adequacy requirements imposed by the Brazilian Central Bank, in line with the Basel Accords. The study also examines the occurrence of income smoothing across credit unions as well as earnings management to avoid reporting losses. The results indicate that the studied institutions do not manage their earnings towards regulatory capital adequacy, but they do engage in income smoothing and earnings management to avoid reporting losses.
\end{abstract}

Keywords: Earnings management; credit union; Basel agreement.

Received 04/13/2013; revised 08/27/2013; accepted 09/27/2013; published 12/13/2013.

*Corresponding Authors

${ }^{\dagger}$. M.A. from Federal University of Minas Gerais Affiliation: Professor Center for Higher Education of Lafaiete, Economic Analyst of Vallourec \& Sumitomo Tubes of Brasil.

Address: Rua Lopes Franco, n. 1001, Carijós, Conselheiro Lafaiete - MG - Brazil

E-mail:

saulomaia@ymail.com Phone: +55-31- 3761-2223
${ }^{\Omega} \mathrm{PhD}$. Applied

Economics, Federal U. of Viçosa

Affiliation: Associate

Professor at Federal

University of Minas Gerais

Address: Av. Antônio

Carlos, n.6627, sala 2041,

Pampulha, Belo Horizonte

- MG - Brazil

E-mail:

vfully@face.ufmg.br

Phone: +55-31-3409-7056
${ }^{¥} \mathrm{PhD}$. Applied Economics, Federal U. of Viçosa Affiliation: Associate Professor at Federal University of Minas Gerais Address: Av. Antônio Carlos, n.6627, sala 2036, Pampulha, Belo Horizonte

- MG - Brazil

E-mail:

wagner@face.ufmg.br

Phone: +55-31-3409-7058
$\$$ Postdoc, University of California at Davis

Affiliation: Associate Professor at Federal University of Viçosa Address: v. P.H Rolfs, s/n, Campus Universitário, Viçosa - MG -

Brazil

E-mail: mjbraga@ufv.br Phone: +55-31-3899-1318

The authors acknowledge the financial support from CAPES, CNPQ and FAPEMIG to the accomplishment of this research.

\section{(cc) $\mathrm{EY}$}

This work is licensed with a Creative Commons License - Attribution 3.0 Not Adapted 


\section{INTRODUCTION}

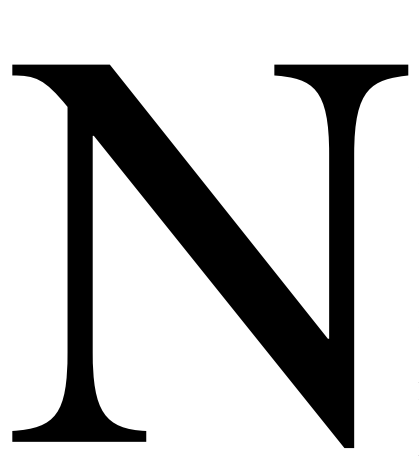

otwithstanding the relevance of earnings management for various types of organizations, the theme has particular importance in the case of financial institutions. Studies such as those by Dantas et al. (2013a), Gabriel \& Corrar (2010) and Goulart (2009) have shown the existence of earnings management by financial institutions in Brazil, a problem that can have a negative impact on the solidity of the nation's financial system. In this respect, this article investigates this theme in a specific segment of financial institutions, not yet studied in Brazil regarding earnings management: credit unions (or "credit cooperatives").

Credit unions are financial institutions in which the members provide both the supply of funds and the demand for loans, with the role of intermediating among their members. By providing a range of financial services to their members, these organizations are important to the development of many countries (Bressan, 2009).

In the international literature, Hillier et al. (2008) and Brown \& Davis (2008) have examined the question of earnings management by Australian credit unions. The results found by these authors were divergent regarding the use of discretionary accounting practices to manage earnings. Therefore, there is no consensus regarding the use of earnings management practices by Australian credit unions.

According to Martinez (2008), it is necessary to understand the particularities of the Brazilian setting that can prompt firms to manage their accounting results. Besides looking for evidence of earnings management, it is necessary to verify the possible motivations for such behavior. In the case of credit unions, there is no motivation to please stock market investors, because Brazilian credit unions' funding comes from their members contributions. Hence, it is necessary to evaluate other aspects that can cause these institutions to manage earnings.

One of these aspects is the need to satisfy capital adequacy requirements, as set forth in the Basel Accords and regulated in Brazil by the Central Bank. With respect to financial institutions in general, the requirement for capital as a motive for earnings management is treated in the academic literature as "capital management", as can be observed in the articles by Moyer (1990), Ahmed et al. (1999) and Santos (2007). Capital management in reality is a modality of earnings management, in which the aim is to improve the proportion of equity capital (by boosting income) in relation to the risks assumed, mainly represented by credit 
transactions and other assets exposed to risks. The need to maintain a minimum level of capital to satisfy the regulations issued by the banking authority is called the "regulatory capital requirement".

According to Hillier et al. (2008), because of the implementation of capital requirement rules, both banks and credit unions are obliged to adjust their capital/risk indexes, with the difference being that unlike banks, credit unions cannot increase their capital by issuing stocks. In this context, credit unions could be motivated to manage their earnings to gain time to adjust the proportion of equity in relation to risk-weighted assets.

In contrast, Brown \& Davis (2008) suggest that since mutual financial institutions such as credit unions can to a certain extent count on the fidelity of their members and typically offer higher interest rates on deposits and lower rates on loans, they have conditions to improve the profitability of their portfolios when they need to improve their performance, without having to engage in earnings management.

The need to maintain the Required Reference Equity (RRE) in Brazil, in line with the Basel Accords, affects credit unions regarding the adequacy of the proportion between riskweighted assets and their reference equity. Credit unions are required to maintain a determined level of equity capital in relation to the volume of their assets, taking into consideration the risk level of these assets. At present, the Required Reference Equity is regulated by a set of rules issued by the National Monetary Council and Brazilian Central Bank.

Besides regulatory requirements, another critical factor for credit unions is their economic performance with respect to their members. According to Ventura et al. (2009), the policy of distributing earnings by credit unions to their members can generate internal pressures for efficiency and orientation to maximize the economic result. This occurs through appropriation of the positive results by the members, in individual form.

In this respect, the question of the bottom-line result for credit unions is just as sensitive as in a listed financial institution, being seen by the members as a mark of the efficiency of managers and the institution itself, for which credibility is vital. Negative or volatile results can denote a situation of risk, conveying the idea of inefficiency and even insecurity in the eyes of the members, who are the owners of the cooperative institution. Besides this, credit unions can apportion losses among members, as allowed by Law 5,764/1971 and Complementary Law ${ }^{\mathrm{i}}$ 130/2009. For these reasons, credit unions can be prompted to manage 
earnings, to smooth earnings or avoid or delay reporting losses, within the law, through the discretionary use of certain accounts, so as not to send a signal of poor performance.

In light of the above, the general objective of this article is to investigate the existence of earnings management as a mechanism to assure capital adequacy, smooth income and avoid reporting losses by credit unions that are part of the System of Credit Cooperatives of Brazil (Sicoob). The study period runs from the first quarter of 2001 to the third quarter of 2011.

This theme is relevant to the Brazilian market because of the large number of credit unions and their growing importance in the national financial system in recent years, as can be observed in Table 1. Therefore, the development of models to identify earnings management in these entities can bring benefits to the Brazilian market, especially for the regulator.

Table 1: Evolution of credit unions in the Brazilian financial system - 2008 - 2012

\begin{tabular}{lccccc}
\hline Item $(\mathrm{R} \$ 1,000)^{\mathrm{ii}}$ & 2008 & 2009 & 2010 & 2011 & 2012 \\
\hline Total Assets & $56,850,460$ & $68,674,216$ & $92,052,086$ & $115,476,661$ & $137,624,131$ \\
Loan Transactions & $26,797,030$ & $31,245,126$ & $38,662,599$ & $49,281,625$ & $61,173,860$ \\
Deposits & $25,057,410$ & $30,515,445$ & $43,971,091$ & $53,607,236$ & $67,118,911$ \\
Net Equity & $9,699,994$ & $11,635,614$ & $13,737,694$ & $16,756,491$ & $20,157,021$ \\
Net Income & 747,296 & 773,885 & $1,017,748$ & $1,289,554$ & $1,461,981$ \\
\hline Source & & &
\end{tabular}

Source: Brazilian Central Bank. Data processed by the authors.

\section{THEORETICAL FRAMEWORK}

2.1 CAPITAL ADEQUACY: THE BASEL ACCORDS AND THE REQUIRED REFERENCE EQUITY (RRE)

Capital adequacy is an expression utilized to describe the adequacy of the net equity of financial institutions in relation to the risks of their assets, transactions, securities trading and other risks associated with their business activities, such as operational risk and market risk. The objective is to assure that banks have sufficient capital in relation to their risks to absorb the highest foreseeable loss and still allow the realization of assets and the raising of new capital. Capital adequacy is dealt with internationally by means of the accords reached under the auspices of the Basel Committee on Banking Supervision. These accords are regulated in Brazil by the regulations issued by the National Monetary Council (CMN) and Brazilian Central Bank, such as the rules on the Required Reference Equity (RRE).

According to Ojo (2010), the "New Basel Capital Accord", or Basel II, proposed by the Basel Committee in 2001, presented a capital adequacy structure based on three pillars: 
minimum capital requirements; supervisory review and market discipline. As clarified by Herring (2007), the Basel II Accord also increased the scope of capital requirements, including operational risk and market risk.

The initiative of the Basel Committee to devise the Basel III Accord, which is in the implementation process in Brazil, corroborates the need for improved banking standards. The Central Bank issued Communication 20,615/2011, containing the preliminary timetable and orientations on future changes in capital requirements in Brazil. The first Basel Accord was only adopted in the country in August 1994, with the publication of Central Bank Resolution 2,099/1994 (Santos, 2007). This required the country's financial institutions to maintain an capital index in relation to risk-weighted assets of 0.08 , a figure that was raised to 0.10 by Resolution 2,399/1997 and then to 0.11 by Circular 2,784/1997. Thereafter, Communication 12,746 of December 2004 marked the start of the incorporation of the requirements proposed by Basel II. Credit unions are subject to this regulatory framework.

Credit unions face some limitations on increasing their capital. They can apportion not only their excess earnings to the members, but also their losses. However, increasing the capital to satisfy the operational limits imposed by regulators is not the same for credit unions as it is for banks with shares listed for public trading. Credit unions do not have access to capital from the stock market. In fact, Complementary Law 130/2009 forbids the distribution of any type of benefit to the holders of the equity units in credit unions besides the distribution of interest on equity, limited to the SELIC rate (the Central Bank's benchmark rate).

Therefore, the formation of the capital stock by credit unions has a more latent institutional character, involving obtaining funding from the members. They capitalize the institution in the expectation of future benefits, in cooperative form, such as through financial services at lower cost than charged by banks, in contrast to stock market investors, whose objective is gain from dividends and/or appreciation of the share price.

\subsection{EARNINGS MANAGEMENT BY FINANCIAL INSTITUTIONS}

Moyer (1990), in a study of the largest commercial banks in the United States, analyzed the incentives of managers to carry out accounting adjustments when the capital index falls below the regulatory minimum, according to the criteria defined by the Federal Reserve Board. She found that adjustments in the provision for bad loans were used to manage the results, and consequently to avoid penalties, by banks with capital/asset ratios below the regulatory minimum. 
Like Moyer (1990), Beatty et al. (1995) also found evidence of a negative relationship between provisions for loan losses and capital ratios, which is consistent with the use of these provisions to reduce the expected regulatory costs associated with violation of the minimum capital requirements. In contrast, Collins et al. (1995) found evidence of a positive relationship between loan loss provisions and reported earnings, which is consistent with the use of these provisions for income smoothing rather than to meet regulatory capital adequacy requirements.

Only a few studies have been published on the specific matter of credit unions and capital adequacy requirements as a motive for earnings management. One is that by Hillier et al. (2008). Their sample was composed of 137 Australian credit unions, nearly half of those operating in the country in the period studied, which covered July 1987 to December 1994 (31 quarterly reports). In summary, they found that the credit unions that were below the capital adequacy threshold 12 months before the introduction of the capital requirement rules brought by the Australian Financial Institutions Code (AFIC) employed accounting strategies to reduce the risk of being placed under "supervision". The strategy most often used was discretionary accounting of provisions for credit transactions.

Brown \& Davis (2008) also studied credit unions in Australia, in the period from 1992 to 2004, after the implementation of the minimum capital index requirements. They pointed out that the return on assets will be greater in credit unions with a lower proportion of capital. However, the results indicated that the cooperatives are able to deal with their members by increasing profitability to meet the required capital ratios, and found no evidence of earnings management.

Hillier et al. (2008) mentioned pragmatic reasons not to alter the interest rates paid on deposits and charged on loans. Credit unions compete with regular banks and any change in rates runs the risk of flight to other financial service providers by current members not willing to subsidize future ones. As a result, managers are not likely to discriminate against any class of members in order to increase profitability, since there is no impediment for members to obtain financial services from other institutions. Under conditions of equal rates, the rational decision of members would be to remain with the credit union, because among other advantages, they have a say in decisions and a share in the earnings. However, if the credit union does not offer competitive services, the members will be motivated to choose other financial institutions. In this context, Hillier et al. (2008) worked with the hypothesis that 
credit union managers use earnings management to respond to the need to satisfy the minimum capital requirement.

\section{METHODOLOGY}

\subsection{ANALYTICAL MODELS}

The panel data analytical models applied here are based on the models of Ahmed et al. (1999) and Shrieves \& Dahl (2003), as adapted by Santos (2007) for the Brazilian market and then adjusted to the specific characteristics of credit unions based on the studies of Brown \& Davis (2008), Hillier et al. (2008) and Bressan (2009). In turn, the histogram analysis is based on the studies of Burgstahler \& Dichev (1997), Martinez (2001), Jacob \& Jorgensen (2007) and Rodrigues et al. (2007).

All the variables in the regression models with panel data, except for the dummy variables and those representing indexes, including macroeconomic ones, were normalized by dividing by the volume of credit transactions, so as not to bias the results due to size differences of the institutions.

Our first hypothesis $\left(\mathrm{H}_{1}\right)$ is: The RRE capital requirement is a factor motivating credit unions to engage in capital management. For this purpose we used the variable Impending RRE Inadequacy (RREInad) as an indicator of credit unions under threat of failing to meet the minimum capital ratio. More specifically, RREInad is a dummy variable that indicates whether a credit union's capital ratio lies in the first quartile of the Basel Index (BI) variable. The BI variable represents the capital adequacy requirement of the Central Bank, according to the RRE rules. RREInad indicates the cooperatives with greater imminence of being penalized for failing to satisfy the RRE. We thus expect a negative sign for RREInad, i.e., credit unions with greater concerns over failure to meet the capital adequacy requirements should have a lower level of provisions. Therefore, we tested the following model:

$$
\begin{gathered}
\mathrm{VNEct}_{\mathrm{it}}=\alpha+\beta_{1} \mathrm{FA}_{\mathrm{it}}+\beta_{2} \mathrm{TA}_{\mathrm{it}}+\beta_{3} \mathrm{VCT}_{\mathrm{it}}+\beta_{4} \mathrm{IPCA}_{\mathrm{it}}+\beta_{5} \mathrm{SELIC}_{\mathrm{it}}+\beta_{6} \mathrm{IBOVESPA}_{\mathrm{it}}+ \\
\beta_{7} \mathrm{GDP}_{\mathrm{it}}+\beta_{8} \mathrm{RREInad}_{\mathrm{it}}+\mathrm{c}_{\mathrm{i}}+\varepsilon_{\mathrm{it}}
\end{gathered}
$$

Where:

VNEct $=$ Variation in net expenses for provision for credit transactions, divided by the volume of those transactions at the start of the period;

$\mathrm{FA}=$ Dummy variable for credit unions of the "free admission" type (not restricted to the employees of a single company or members of a particular profession or community), assuming the value of 1 for free-admission cooperatives and zero otherwise;

$\mathrm{TA}=$ Time of activity in years; 
$\mathrm{VCT}=$ Variation in the volume of credit transactions;

IPCA = Consumer price index;

SELIC $=$ Variation of the SELIC rate in the period;

IBOVESPA = Variation of the IBOVESPA in the period;

GDP $=$ Variation of GDP in the period;

RREInad = Impending failure to satisfy the RRE.

In the majority of studies of earnings management by financial institutions, the expenses for loan loss provisions appear as a dependent variable, since these are considered one of the main accruals in the financial sector, as described by Ahmed et al. (1999). In the case of credit unions, like other financial institutions, these provisions are formed and accounted for according to the rules for the sector. In Brazil, the main document in this respect is CMN Resolution 2,682/1999, which although defining objective criteria for classification of loans as nonperforming, also allows some space for discretionary choices.

The second hypothesis tested is $\mathrm{H}_{2}$ : Credit unions in Brazil engage earnings management for the purpose of income smoothing. For this hypothesis we used the independent variable Non-Discretionary Result (NDRct), which is the result after net provision expenses divided by the total of credit transactions.

We expect to obtain a positive sign for NDRct, because when this variable is increasing, there should also be an increase in net provision expenses, in view of the reduction of earnings and smoothing of the final result. On the other hand, when NDRct is smaller, the incentive will be to reduce the VNEct. Therefore, when there is higher provisioning motivated by a larger accounting result, so as to smooth income, earnings management is present. This setup is in line with the models used by Martinez (2001), Ahmed et al. (1999) and Goulart (2007). To test hypothesis $\mathrm{H}_{3}$, we used the following model:

$$
\begin{gathered}
\mathrm{VNEct}_{\mathrm{it}}=\alpha+\beta_{1} \mathrm{FA}_{\mathrm{it}}+\beta_{2} \mathrm{TA}_{\mathrm{it}}+\beta_{3} \mathrm{VCT}_{\mathrm{it}}+\beta_{4} \mathrm{IPCA}_{\mathrm{it}}+\beta_{5} \mathrm{SELIC}_{\mathrm{it}}+\beta_{6} \mathrm{IBOVESPA}_{\mathrm{it}}+ \\
\beta_{7} \mathrm{GDP}_{\mathrm{it}}+\beta_{8} \mathrm{NDRct}_{\mathrm{it}}+\mathrm{c}_{\mathrm{i}}+\varepsilon_{\mathrm{it}}
\end{gathered}
$$

In model 2, if the parameter of the variable NDRct is statistically significant and positive, it will indicate that the higher the nondiscretionary result is, the greater the expense will tend to be from provisions for credit transactions, providing evidence of income smoothing. The other variables in model 2 are control variables.

Our final hypothesis is $\mathrm{H}_{3}$ : Brazilian credit unions engage in earnings management to avoid reporting losses. In this case, the analysis is of frequency in histograms. 
Assuming the hypothesis of earnings management to avoid losses means that if the enterprise (here a credit union) incurs a small loss in a determined period, it will use earnings management practices, by increasing revenues and/or reducing expenses, so as to show a small gain (Goulart, 2007). This situation was adapted to credit unions, since the members can have a disproportionately negative reaction to losses, even if small, providing an incentive for managers to show small earnings.

\subsection{OPERATIONAL PROCEDURES TO ESTIMATE THE PANEL DATA MODELS}

The strategy utilized to select the best specification of models here consisted first of estimating models with pooled ordinary least squares (pooled OLS) and with fixed effects, to test, via the Chow test (F test), the null hypothesis that the pooled OLS model is preferable to the fixed effects model. The second step entailed estimating the model with random effects and applying the Breusch-Pagan test (a Lagrange multiplier test) to check the null hypothesis that the pooled OLS model is preferable to the random effects model. The third step consisted of applying the Hausman test to verify the null hypothesis that the random effects estimator, for being consistent and efficient, is preferable to the estimator of the model with fixed effects, which is only consistent. Since from these three steps, the fixed effects model was chosen, then a fourth step was performed, consisting of testing for autocorrelation of the errors with the test proposed by Wooldridge (2002) and testing for group heteroscedasticity with the Wald test. Finally, when autocorrelation and heteroscedasticity were confirmed, the model with fixed effects was re-estimated via feasible generalized least squares (FGLS), as suggested by Judge et al. (1985) and Davidson \& MacKinnon (1993).

\subsection{SAMPLE AND SOURCE OF DATA}

The credit unions of interest here are singular cooperatives that are Sicoob members, which we chose because it is the largest system of credit unions in Brazil in number of members. Singular credit unions are financial institutions intended to provide mutual financial services to their members to assure their access to financial market instruments. Such credit unions can join together in central cooperatives to organize their economic and assistance services on a larger scale (Brasil, 2009). Therefore, central cooperatives are in reality cooperatives of cooperatives. Because they have operational characteristics distinct from singular credit unions - among them not operating directly with the members of the singular credit unions, but rather with those cooperatives - the central credit cooperatives were not the subject of this study. It should be stressed that the choice of a system of credit unions and the evaluation of the numbers of its singular members can cause selection bias in the results, since 
these can be influenced by the specific characteristics of the institutions included in the sample.

According to data from the Brazilian Central Bank, in December 2011 the Sicoob was composed of 679 credit unions - 665 singular and 14 central ones. The data used in this study form an unbalanced panel with quarterly observations of 405 credit singular unions affiliated with Sicoob, not classified as the "capital-loan" type ${ }^{\text {iii }}$, that had at least 12 months of operation, from the first quarter of 2001 to the third quarter of 2011. These represented approximately $60 \%$ of the singular credit unions of the referred system and $31 \%$ of the total in Brazil in the period studied. The data, obtained from the Brazilian Central Bank, are confidential and only available from that source. We used data starting in 2001 to avoid possible distortions because of the start of implementation of CMN Resolution 2,682/1999, which took effect in March 2000, involving provisions for loan losses.

\section{ANALYSIS OF THE RESULTS}

Table 2 reports the descriptive statistics of the variables used in this study, referring to the 405 singular credit unions of Sicoob, in 43 quarterly periods, from the first quarter of 2001 to the third quarter of 2011.

Table 2: Descriptive statistics of the variables - Sicoob 1st quarter 2001 - 3rd quarter 2011

\begin{tabular}{lr|r|r|r|r}
\hline \multicolumn{1}{c}{ Statistics } & VNEct & VCT & TA & NDRct & BI \\
\hline Minimum & - & -0.9872 & \multicolumn{1}{c|}{1} & -2.6437 & -1.9838 \\
& 0.8762 & & & & \\
Maximum & 0.9276 & 1.0000 & 45 & 0.6880 & 2.8909 \\
Median & 0.0042 & 0.0522 & 11 & 0.0233 & 0.2984 \\
Mean & 0.0095 & 0.0562 & 12.49 & -0.0105 & 0.3659 \\
Standard Dev. & 0.0378 & 0.1487 & 8.6 & 0.2219 & 0.4740 \\
Coeff. Var. & 3.9789 & 2.6459 & 0.69 & -21.133 & 1.2954 \\
\hline
\end{tabular}

VNEct: Variation of net expenses from provision for credit transactions, divided by volume of credit transactions at the start of the period

VCT: Variation in volume of credit transactions

TA: Time of operation in years

NDRct: Nondiscretionary result divided by credit transactions

BI: Basel Index

Source: Research data 
It should initially be noted that the macroeconomic control variables (IPCA, SELIC, GDP and Ibovespa) are highly correlated, so we chose to maintain among them in the panel data regression model only those best able to explain the dependent variable VNEct. The macroeconomic variable GDP was the only statistically ${ }^{\text {iv }}$ significant one and presented a negative sign, as expected, so we only kept this macroeconomic variable in the model.

\subsection{CAPITAL MANAGEMENT}

In this section we present the results of the tests of hypothesis $\mathrm{H}_{1}$ : The RRE capital requirement is a factor motivating credit unions to engage in capital management.

The dummy variable RREInad, identifying observations in the first quartile of the Basel Index, was applied to verify whether the credit unions were engaging in capital management, i.e., managing results to improve the capital requirement indicator, measured by the BI. The variable was not statistically significant, contrary to expectation (Table 3). Therefore, the model did not provide evidence that the Sicoob credit unions, in the period analyzed, used net expenses for provisions for credit transactions for the purpose of capital management. Hence, there is insufficient evidence to confirm hypothesis $\mathrm{H}_{1}$ : The RRE capital requirement is a factor motivating credit unions to engage in capital management.

Table 3: Results of estimating the model with panel data to evaluate whether credit unions managed regulatory capital by means of net expenses for provision for credit transactions, using the explanatory variable RREInad as a proxy for a weak regulatory capital position, among credit unions affiliated with Sicoob, in the period from March 2001 to September 2011

\begin{tabular}{|c|c|c|c|}
\hline VNEct & Coefficient & Standard Error & P-Value \\
\hline VCT & 0.0006293 & 0.0003258 & 0.053 \\
\hline TA & 0.0000485 & 0.0000184 & 0.009 \\
\hline FA & 0.0002756 & 0.000192 & 0.151 \\
\hline GDP & -0.0035674 & 0.001074 & 0.001 \\
\hline RREInad $_{\mathrm{t}-1}$ & 0.000205 & 0.0001952 & 0.294 \\
\hline Constant & 0.0009761 & 0.0010493 & 0.352 \\
\hline
\end{tabular}

\begin{tabular}{clll}
\hline \multicolumn{2}{c}{ Number of observations: 15357} & Number of groups: 405 & \\
\hline Observations per group: & Minimum $=4$ & Mean $=37.89$ & Maximum $=43$ \\
\hline Wald $\chi^{2}(9)=4093.90$ & & Prob $>\chi^{2}=0.000$ &
\end{tabular}

Description of the dependent variable:

Variation of net expense for provision over credit transactions

\section{Explanatory variable of research interest:}

RREInadt-1: Impending Inadequacy dummy in quarter $\mathrm{t}-1$, according to the 1 st quartile of the BI

Remark: Estimated by FGLS, assuming dummies for fixed effects and considering the problem of heteroscedasticity detected in the operational procedures.

Source: Research results 
The absence of capital management by credit unions, in contrast to the behavior of the country's large banks, according to the evidence found by Santos (2007), can be explained by the low leverage situation of credit unions compared to banks. In a meeting with technical staff of the Central Bank, this positive aspect of credit unions was pointed to as a factor that can eliminate the motivation to engage in capital management.

\subsection{EARNINGS MANAGEMENT FOR INCOME SMOOTHING}

In this section we evaluate hypothesis $\mathrm{H}_{2}$ : Credit unions in Brazil engage earnings management for the purpose of income smoothing.

The variable NDRct was statistically significant, at the $1 \%$ level, to explain the variations in net provision expenses (Table 4). The parameter of the variable was positive, indicating that the higher the result before net provision expenses, the greater the net provision expenses tended to be. The positive and significant parameter evidences that in the period analyzed the credit unions affiliated with Sicoob used discretionary provisions for loan losses to smooth their quarterly results. This evidence leads to the non-rejection of hypothesis $\mathrm{H}_{2}$.

Table 4: Results of estimating the model with panel data to evaluate whether the credit unions affiliated with Sicoob used net expenses for provision for credit transactions to smooth income, in the period from March 2001 to September 2011

\begin{tabular}{lrrr}
\hline VNEct & Coefficient & Standard Error & P-Value \\
\hline VCT & 0.0012619 & 0.0003506 & 0.000 \\
TA & 0.000056 & 0.0000196 & 0.004 \\
FA & 0.0003006 & 0.0002026 & 0.138 \\
GDP & -0.004492 & 0.0010613 & 0.000 \\
NDRct & 0.0045106 & 0.0009157 & 0.000 \\
Constant & 0.0007222 & 0.0010988 & 0.511 \\
\hline
\end{tabular}

Number of observations: 15289

Number of groups: 405

\begin{tabular}{|c|c|c|c|}
\hline Observations per group: & Minimum $=4$ & Mean $=37.75$ & Maximum $=43$ \\
\hline
\end{tabular}

Description of the dependent variable:

Variation in net expense for provision for credit transactions

Explanatory variable of research interest:

NDRct: Non-discretionary result divided by credit transactions at the start of the period

Remark: Estimated by FGLS, assuming dummies for fixed effects and considering the problem of heteroscedasticity detected in the operational procedures.

Source: Research results 
In a meeting with technical staff members of the Central Bank, they expressed a low expectation of finding evidence of quarterly income smoothing by credit unions, since this result is only disclosed to members twice a year, and in special character once more at the time of the annual general meeting On the other hand, the results are sent monthly to the Central Bank, to enable it to monitor performance on a more timely basis than just at the time of disclosing the financial statements. Credit unions also report their results to central cooperatives. This makes it relevant for singular credit unions not to show great income fluctuations, since volatility in this respect can demote an increase in risk.

\subsection{EARNINGS MANAGEMENT TO AVOID REPORTING LOSSES}

To detect the presence of earnings management to avoid reporting losses (hypothesis $\mathrm{H}_{3}$ ), we analyzed the frequency distribution of the credit unions' bottom-line results. For this purpose, we used the semiannual results of the Sicoob credit unions between the first half of 2001 and first half of 2011 , for a sample of 21 periods over 10 years. The annual results only cover from 2001 to 2010, since the final first-half figures are only available at the end of the third quarter. Graph 1 shows the frequency distribution of the annual results of the sample of credit unions, divided by the volume of credit transactions.

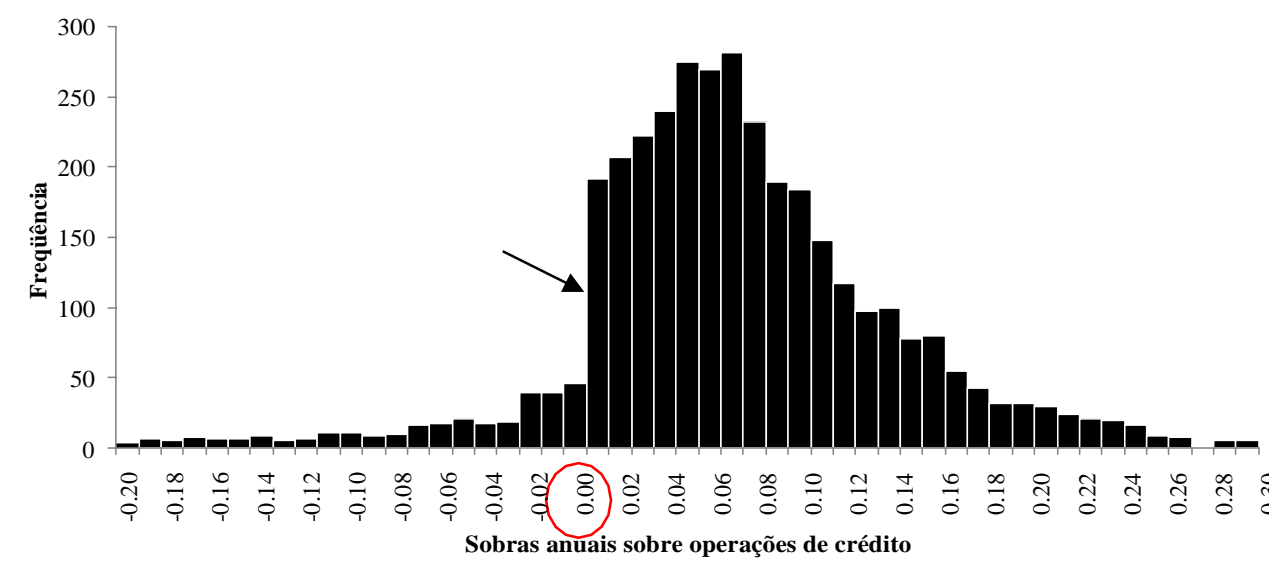

Graph 1: Frequency distribution of the annual results of the credit unions affiliated with Sicoob between 2001 and 2010, divided by volume of credit transactions.

Source: Research results

According to the usual assumptions in the literature, the situation presented in Graph 1 provides evidence that in the period studied the credit unions managed their earnings so as not to report losses. Nota the large variation in the frequency distribution just to the right of zero (0.00). This leads to non-rejection of hypothesis $\mathrm{H}_{3}$ : Brazilian credit unions engage in earnings management to avoid reporting losses. 
Graph 2 provides evidence that the credit unions affiliated with Sicoob also manage their semiannual earnings, but to a lesser degree than their annual results. Assuming the hypothesis of earnings management to avoid reporting losses, the comparison between the two graphs suggests that credit union managers find it more important not to report annual than semiannual losses. The semiannual results are published in newspapers with regional circulation in the area where the credit unions operate, but are not disclosed in general meetings of members.

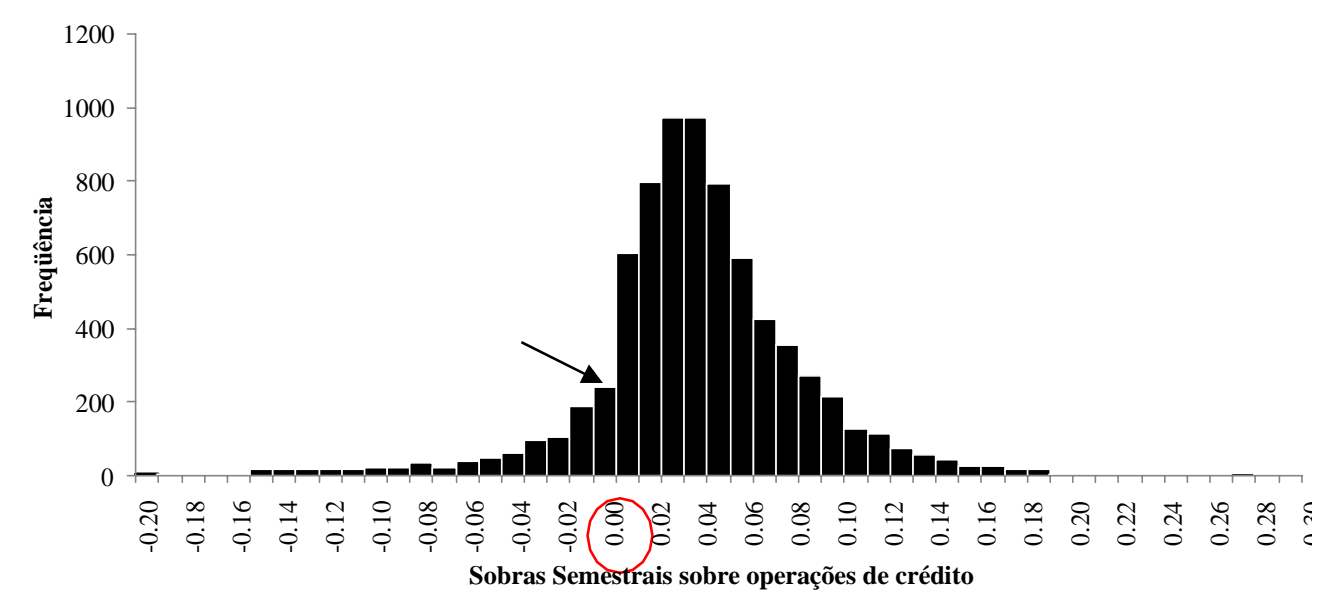

Graph 2: Frequency distribution of the semiannual results of the credit unions affiliated with Sicoob between the first half of 2001 and the first half of 2011

Source: Research results

At the time of disclosing the annual results, credit union managers are more in the limelight among the members than when the semiannual results are disclosed. Furthermore negative results in the first half year can be offset against positive results in the second half, so that negative first-half results do not necessarily mean a loss for the entire year.

\section{FINAL CONSIDERATIONS}

This study investigated whether Brazilian credit unions affiliated with the System of Credit Cooperatives of Brazil (Sicoob) engaged in practices to manage their results in the period between 2001 and 2011. The results of the regressions refute the hypothesis of management of regulatory capital, as measured by the Basel Index. This finding runs counter to that of Santos (2007) in relation to large banks in Brazil. The rejection of hypothesis $\mathrm{H}_{1}$ can be explained by the fact that credit unions usually have lower leverage than banks, so they generally have a different situation in relation to capital adequacy. This aspect was previously indicated by technical staff members of the Brazilian Central Bank as a possible reason for credit unions not to engage in capital management. 
Another explanation for the absence of capital management by credit unions is that, according to the research findings, there is evidence that other types of result management are more relevant for these institutions. In this respect, the results of this study are compatible with those of the study by Brown \& Davis (2008) of credit unions in Australia.

The capital requirement can influence the volume of credit extended. Therefore, another solution that can be adopted by credit unions to improve their capital ratio is to slow down or even suspend new lending, allowing replenishment of their regulatory capital by amortization of existing loans. Since the results suggest that credit unions in a worse situation regarding the Required Reference Equity (RRE) do not adopt capital management as a solution, it is possible they employ other strategies to improve their capital ratios in relation to the Basel Index.

The results found for the test of the hypothesis of income smoothing contain evidence that in the period analyzed the credit unions in question used the discretionary leeway in establishing provisions for bad loans to smooth income. This is indicated by the finding that the larger the result before such provisions for credit transactions, the greater the variation in these provisions tended to be. Thus, there is evidence that in the occurrence of higher nondiscretionary results, the credit unions tend to maximize the provisions, and do the opposite in response to lower nondiscretionary results, to reduce the variability of income.

This income smoothing by credit unions can be explained by the fact their accounting information is regularly monitored by the Central Bank. Besides this, the singular credit unions are also monitored by central cooperatives. This makes it important for credit unions not to show large oscillations in their results, since volatility can denote heightened risk.

There is also evidence not to reject the hypothesis that the credit unions affiliated with Sicoob manage earnings to avoid reporting losses, in semiannual periods and more so in the yearly results. The evidence indicates a frequency greater than expected to show positive results near zero and a lesser frequency of showing negative results near zero.

Although there are technical limitations regarding the method used to confirm or reject this last hypothesis, the "anormal" frequency distribution around zero is usually assumed in the literature as an indication of earnings management to avoid reporting losses. Furthermore, among the types of result management investigated, the aversion to reporting losses was indicated as most expected by the technical staff members of the Central Bank. 
The evidence of earnings management to avoid reporting losses can be explained by the fact that the results of credit unions are important indicators of their efficiency. Besides serving as a performance indicator, they also serve as an indicator of good (or bad) direction, so they have a strong impact on the reputation of credit union managers among the members. Added to this is the fact that credibility is essential in any financial institution, more so in credit unions, which do not have the backing of large conglomerates. The fact that negative results can be disproportionately interpreted in relation to positive ones explains the tendency to turn small negative results into small positive ones, relying on the discretionary margin in preparing the financial statements within the legal limits, characterizing earnings management.

The main contribution of this study, through analysis of the set of hypotheses employed, is the finding that capital adequacy is not a factor exercising strong influence on the discretionarity of accruals, and consequently on the accounting result of credit unions. The non-rejection of the hypotheses of earnings management for income smoothing and to avoid reporting losses evidences that the accounting result - not for its consequences on capital adequacy, but rather for its character as a performance indicator - is an important variable for singular credit unions in Brazil. Although they are nonprofit institutions, they tend to have excess earnings, which act as an indicator of solidity and credibility. The conclusions presented here indicate that credit unions treat their bottom-line results with special care with respect to their owners, the members, as well as to central cooperatives and the Central Bank. The findings obtained can imply modifications in the oversight by the Central Bank, based on additional information for monitoring the accounts of credit unions, especially regarding their net result, which is a sensitive item for the market.

These results are restricted to the credit unions affiliated with Sicoob. Even though it is the system with the largest number of credit unions, the results should not be taken as representing all credit unions in Brazil. Therefore, future studies can focus on other Brazilian credit unions, particularly those associated with the Sicredi, Unicred and Confessol systems, as well as unaffiliated (independent) ones. Additionally, we suggest the use of two-stage models to evaluate the use of discretionary accruals to manage results, as recently proposed by Dantas et al. (2013b), with the proper adaptations to credit unions. It would also be important to use alternative proxies for capital adequacy, such as taking inadequacy to be capital ratios near the minimum required by the Central Bank rather than the first quartile of the Basel Index. 


\section{REFERENCES}

AHMED, Anwer S; TAKEDA, Carolyn; THOMAS, Shawn. Bank loan loss provisions: a reexamination of capital management, earnings management and signaling effects. Journal of Accounting \& Economics, v. 28, p. 1-25, 1999.

BALTAGI, Badi Hani; Wu Ping X.. Unequally spaced panel data regressions with AR(1) disturbances. Econometric Theory, vol.15, p. 814-823, 1999.

BEATTY, A., CHAMBERLAIN, S., MAGLIOLO, J. Managing financial reports of commercial banks: the influence of taxes, regulatory capital and earnings. Journal of Accounting Research. 1995. n. 33, p. 231-262.

BRASIL. Lei n ${ }^{\circ}$ 5.764, de 16 de dezembro de 1971. Define a Política Nacional de Cooperativismo, institui o regime jurídico das sociedades cooperativas, e dá outras providências. Diário Oficial [da] República Federativa do Brasil, Brasília, 16 dez. 1971.

BRASIL. Lei Complementar $\mathrm{n}^{\circ}$ 130, de 17 de abril de 2009. Dispõe sobre o Sistema Nacional de Crédito Cooperativo e revoga dispositivos das Leis 4.595, de 31 de dezembro de 1964, e 5.764, de 16 de dezembro de 1971. Diário Oficial [da] República Federativa do Brasil, Brasília, 17 abr. 2009.

BRESSAN, Valéria Gama Fully. Seguro depósito e Moral Hazard nas cooperativas de crédito brasileiras. 2009. $371 \mathrm{f}$. Tese (Doutorado em Economia Aplicada) - Departamento de Economia Rural, Universidade Federal de Viçosa, Viçosa, 2009.

BROWN, Cristine; DAVIS, Kevin. Capital management in mutual financial institutions. Journal of Banking \& Finance, 2008, n 33, p 443-445.

BURGSTAHLER, D.; DICHEV, I. Earnings management to avoid earnings decrease and losses. Journal of Accounting \& Economics, North-Holland, v.24, n.1, p.99-126, Dec. 1997.

COLLINS, J., SHACKELFORD, D., WAHLEN, J.. Bank differences in the coordination of regulatory capital, earnings and taxes. Journal of Accounting Research. 1995. n. 33, p. 263 292.

COMITÊ DE PRONUNCIAMENTOS CONTÁBEIS (CPC). Pronunciamento conceitual básico. Estrutura conceitual para a elaboração e apresentação das demonstrações contábeis. 2008. Disponível em: http://www.cpc.org.br/pdf/pronunciamento_conceitual.pdf >. Acesso em: 15 mar. 2011.

COMISSÃO DE VALORES MOBILIÁRIOS (CVM). Ofício-Circular CVM/SNC/SEP no 01/2007. Orientações gerais sobre procedimentos a serem observados pelas companhias abertas. 2007.

DANTAS, José Alves ; GALDI, Fernando. Caio. ; CAPELLETTO, Lúcio Rodrigues. ; MEDEIROS, Otávio Ribeiro de. Discricionariedade na Mensuracão de Derivativos como Mecanismo de Gerenciamento de Resultados em Bancos. Revista Brasileira de Finanças, v. 11, p. 17-48, 2013.

DANTAS, José Alves ; MEDEIROS, Otávio Ribeiro de; GALDI, Fernando Caio ; COSTA, Fábio Moraes da . Gerenciamento de resultados em bancos com uso de TVM: validação de 
modelo de dois estágios. Revista Contabilidade \& Finanças, v. 24, p. 37-54, 2013

DAVIDSON, Russel; MacKINNON, James G. Estimation and Inference in Econometrics. New York: Oxford University Press. 1993.

GABRIEL, F., \& CORRAR, L. J. (2010, maio-agosto). Gerenciamento de resultados e de capital no sistema bancario brasileiro silei investigacao empirica nas aplicacoes em titulos e valores mobiliarios. Revista de Contabilidade do Mestrado em Ciencias Contabeis da UERJ. Rio de Janeiro, 15 (2), 49-62.

GOULART, A. M. C. Gerenciamento de resultados contábeis em instituições financeiras no Brasil. 219 f. Tese (Doutorado em Ciências Contábeis) - FEA -USP, São Paulo, 2007.

HANSEN, Christian B. Generalized least squares inference in panel and multilevel models with serial correlation and fixed effects. Journal of Econometrics, vol 140, p. 670-694, 2007.

HERRING, Richard J. The Rocky Road to Implementation of Basel II in the United States. Atlantic Economic Journal. 2007. V.35. nº 4. p. 411-429.

HILLIER, David; HODGSON, Allan; STEVENSON-CLARKE, Peta; LHAOPADCHAN, Suntharre. Accounting Window Dressing and Template Regulation: A Case Study of the Australian Credit Union Industry. Journal of Business Ethics, 2008, v.83 nº 3, p. 579-593.

HYUN, Jong-Soon; RHEE, Byung-Kun. Bank Capital Regulation and Credit Supply. Journal of Banking \& Finance. 2011, n 35, p. 323-330.

IUDÍCIBUS, Sérgio de. Teoria da Contabilidade. 8. Ed. São Paulo: Atlas, 2006.

JACOB, John; JORGENSEN, Bjorn N. Earnings Management and accounting income aggregation. Journal of Accounting and Economics. 2007, n. 43, p. 369-390, Jan. 2007.

JUDGE, Gerge G.; GRIFFITHS, William E.; HILL, R.Carter; LÜTKEPOHL, Helmut. The Theory and practice of Econometrics. 2ed. New York: Wiley, 1985.

MARTINEZ, Antonio Lopo. “Gerenciamento" dos resultados contábeis: estudo empírico das companhias abertas brasileiras. Tese (Doutorado em Ciências Contábeis), FEA-USP, São Paulo, 2001.

MARTINEZ, Antônio Lopo. Detectando Earnings Management no Brasil: Estimando os Accruals Discricionários. Revista Contabilidade \& Finanças, USP, São Paulo. V.19. n. 16. p. 7-17. Janeiro/Abril 2008.

MOYER, Susan E. 1990. Capital adequacy ratio regulations and accounting choices in commercial banks. Journal of Accounting \& Economics, n. 13, p. 123-154, 1990.

OJO, Marianne. Risk management by the Basel Committee: Evaluating progress made from the 1988 Basel Accord to recent developments. Journal of Financial Regulation and Compliance. V. 18. n. 4. p. 305-15. 2010.

RODRIGUES, Adriano; PAULO, Edilson; CARVALHO, L. Nelson. Gerenciamento de resultados por meio das transações entre companhias brasileiras interligadas. RAUSPRevista de Administração, v. 42, p. 216-226, 2007. 
SANTOS, Eliana Calixto. Capital regulatório e gerenciamento de resultados nas instituições financeiras que atuam no Brasil. 2007. 128 f. Dissertação (Mestrado em Ciências Contábeis) - Programa de Pós-Graduação em Ciências Contábeis da Fundação Instituto Capixaba de Pesquisas em Contabilidade, Economia e Finanças - FUCAPE, Vitória, 2007.

SOARES, Marden Marques, MELO SOBRINHO, Abelardo Duarte de. Microfinanças: O papel do Banco Central e a Importância do Cooperativismo de Crédito. $2^{\mathrm{a}}$ ed. Brasília: BCB, 2008

SHRIEVES, Ronald E; DAHL, Drew. Discretionary Accounting and the Behavior of Japanese Banks under Financial Duress. Journal of Banking and Finance, Vol. 27, p. 1219$1243,2003$.

SMITH, D. J.; Cargill T. F.; R. A. Meyer: 1981, An Economic Theory of a Credit Union, Journal of Finance, 36, 519-528.

VENTURA, Elvira Cruvinel Ferreira (Org). Governança Cooperativa: Diretrizes e mecanismos para o fortalecimento da governança em cooperativas de crédito do Brasil. Brasília: BCB, 2009. Disponível em: <http://www.bcb.gov.br>. Acesso em: 30 nov. 2010.

WOOLDRIGDE, Jeffrey M. Econometric Analysis of Cross Section and Panel Data. Cambrigde, MA: MIT Press, 2002.

\footnotetext{
${ }^{\mathrm{i}}$ The complementary Law is an enabling law of constitutional provisions, with higher status than ordinary law.

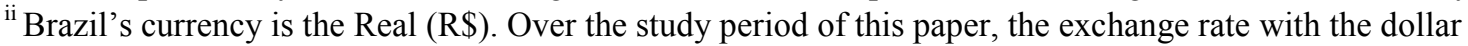
fluctuated in an interval between approximately $\mathrm{R} \$ 1.65$ to $\mathrm{R} \$ 3.10 / \mathrm{US} \$$, with a rough average of R\$2.20/US\$. iii These credit unions (capital-empréstimo) are small cooperatives, generally serving the employees of one company, that offer a very limited range of services.

${ }^{\text {iv }}$ Readers interested in the statistical procedures applied to select the macroeconomic variable employed in this article can contact the authors directly
} 